\title{
Ad lib. feeding during recovery from malnutrition
}

\author{
BY ANN ASHWORTH \\ Tropical Metabolism Research Unit, University of \\ the West Indies, Kingston 7, Famaica \\ (Received I I fune I973-Accepted 31 fuly 1973)
}

1. Ten severely malnourished children were studied.

2. During recovery the mean energy intake was $916 \mathrm{~kJ}(2 \mathrm{Ig} \mathrm{kcal}) / \mathrm{kg}$ per $\mathrm{d}$ when the children were fed $a d l i b$, on a high-energy milk preparation.

3. When a lower-energy milk preparation was given ad lib. the children voluntarily increased the volume consumed but the mean energy intake fell to $703 \mathrm{~kJ}$ ( $168 \mathrm{kcal}$ ) $/ \mathrm{kg}$ per d.

4. After recovery the children no longer consumed an increased volume when the lowerenergy milk preparation was offered.

5. The results provide further evidence of the importance of feeding with a high-energy preparation for the treatment of malnutrition, and demonstrate that additional benefits can be obtained by offering such mixtures ad lib.

In order to achieve rapid 'catch-up' growth, malnourished children in our ward are routinely fed on a high-energy milk preparation (Ashworth, Bell, James \& Waterlow, I968). Until recently the amount prescribed for each child was rather arbitrary, but the intakes of the majority of children were of the order of $669-753 \mathrm{~kJ} /$ $\mathrm{kg}$ per $\mathrm{d}(\mathrm{I} 60-180 \mathrm{kcal} / \mathrm{kg}$ per d). Although these intakes are almost twice as great as those of normal healthy children of the same age, the children still appeared hungry and willing to take more. We have therefore fed recovering malnourished children $a d l i b$. in order to determine the upper limit of their appetite. In addition, we wished to know whether children fed on an unmodified preparation would consume more in order to keep their energy intakes high.

\section{METHODS}

\section{Subjects}

Ten severely malnourished children were investigated and their ages on admission ranged from 6 to 18 months. The children were studied during the phase of rapid growth and six of them were studied again after they had reached their expected weight for height. We used as our standards the 5 oth percentile figures for American children (Nelson, Vaughan \& McKay, I969).

\section{Dietary regimen}

The treatment of the children on admission to hospital was as described by Garrow, Picou \& Waterlow (I962). When diarrhoea, vomiting and other disturbances had been controlled the children were fed on the routine high-energy milk preparation in the usual way. As soon as the children were feeding well, one of the two test mixtures (milk A or milk B, Table I) was given ad lib. Milk A was essentially the 
Table 1. Composition per l of the milk preparations

$\begin{array}{lccc} & \begin{array}{c}\text { Routine milk } \\ \text { preparation }\end{array} & \text { Milk A } & \text { Milk B } \\ \text { Dried full cream milk* }(\mathrm{g}) & \mathrm{r} 90 & \mathrm{~g} 90 & \mathrm{r} 90 \\ \text { Arachis oil }(\mathrm{g}) & 60 & 60 & - \\ \text { Ovaltine }(\mathrm{g}) & - & 50 & 50 \\ \text { Energy }(\mathrm{kJ}) & 5940(\mathrm{I} 420 \mathrm{kcal}) & 6740(\mathrm{r} 6 \mathrm{10} \mathrm{kcal}) & 4390(\mathrm{r} 050 \mathrm{kcal}) \\ \text { Protein }(\mathrm{g}) & 3 \mathrm{r} & 3^{8} & 3^{8}\end{array}$

* A proprietary preparation which incorporates maize starch, dextrin-maltose and sucrose; total carbohydrate $570 \mathrm{~g} / \mathrm{kg}$, fat $I 70 \mathrm{~g} / \mathrm{kg}$, protein $165 \mathrm{~g} / \mathrm{kg}$.

routine high-energy milk preparation; milk $\mathrm{B}$ was identical in protein content to milk $\mathrm{A}$ but had a lower energy density since no oil was added. Both test mixtures were flavoured to avoid prejudicing the results by prior experience of the high-energy preparation and to mask any difference in the taste of the two test milks. Ovaltine was found to be a satisfactory flavouring agent although the testing had to be conducted with adults.

Each test preparation was offered six times daily for 5 consecutive days, and the sequence in which they were given was reversed in alternate subjects. All dietary intakes were measured very carefully.

\section{RESULTS}

Results for individual children are shown in Table 2.

During rapid 'catch-up' growth the energy intakes of the children given milk A ad lib. ranged from 623 to $1226 \mathrm{~kJ} / \mathrm{kg}$ per $\mathrm{d}$ with a mean of $916 \mathrm{~kJ} / \mathrm{kg}$ per d $(2 \mathrm{I} 9 \mathrm{kcal} /$ $\mathrm{kg}$ per d). When milk $\mathrm{B}$ was given the children voluntarily increased the volume consumed $(P<0.01)$. Although the increase was statistically significant it was not sufficient to compensate for the difference in energy value and the intakes of children given milk $\mathrm{B}$ ad lib. were lower $(P<0.0 \mathrm{r})$, ranging from 540 to $803 \mathrm{~kJ} / \mathrm{kg}$ per $\mathrm{d}$ with a mean of $703 \mathrm{~kJ} / \mathrm{kg}$ per d (I $68 \mathrm{kcal} / \mathrm{kg}$ per d).

When the study was repeated with six of the children after they had reached their expected weight for height it was found that the children no longer consumed an increased volume when milk B was offered. The mean energy intakes with ad lib. feeding after recovery were $5^{1} 5$ and $368 \mathrm{~kJ} / \mathrm{kg}$ per $\mathrm{d}(\mathrm{I} 23$ and $89 \mathrm{kcal} / \mathrm{kg}$ per d) for milks $\mathrm{A}$ and $\mathrm{B}$ respectively.

There were no significant differences in protein intake expressed per $\mathrm{kg}$ body-weight when the two milks were compared, either during rapid growth or after recovery.

\section{DISCUSSION}

This study demonstrates how well young children can adjust their food intakes to meet their needs. During recovery the intakes of the majority of the children exceeded $850 \mathrm{~kJ} / \mathrm{kg}$ per $\mathrm{d}$ when milk $\mathrm{A}$ was given and they attempted to compensate for the lower energy content of milk B by increasing the volume consumed. In contrast, after recovery only one child (J.R.) consumed an appreciably greater volume when 
Table 2. Intakes of milks $A$ and $B$ (see Table $\mathrm{r}$ ) offered ad lib. to malnourished children during rapid growth and after recovery

\begin{tabular}{|c|c|c|c|c|c|c|c|}
\hline \multirow[b]{2}{*}{ Child } & \multirow{2}{*}{$\begin{array}{l}\text { Age of } \\
\text { admission } \\
\text { to hospital } \\
\text { (months) }\end{array}$} & \multicolumn{2}{|c|}{ Volume (ml) } & \multicolumn{2}{|c|}{ Energy $(\mathrm{kJ} / \mathrm{kg}$ per $\mathrm{d})$} & \multicolumn{2}{|c|}{ Protein (g/kg per $d)$} \\
\hline & & A & $\mathrm{B}$ & A & $\mathrm{B}$ & A & $\mathbf{B}$ \\
\hline \multicolumn{8}{|c|}{ During rapid growth } \\
\hline $\mathrm{FH}$ & 15 & 1025 & $127 \mathrm{I}$ & 774 & 590 & $4 \%$ & $5^{\cdot} \mathrm{I}$ \\
\hline $\mathrm{JM}$ & 18 & II3I & 1254 & 854 & 540 & $4 \cdot 8$ & $4 \cdot 6$ \\
\hline DB & 18 & 1273 & 1572 & 1008 & 749 & $5 \cdot 7$ & $6 \cdot 5$ \\
\hline $\mathrm{JH}$ & I5 & $95^{2}$ & 1273 & 816 & 803 & $4 \cdot 6$ & $6 \cdot 9$ \\
\hline $\mathrm{ES}$ & II & 734 & 1321 & 623 & 762 & $3 \cdot 5$ & $6 \cdot 5$ \\
\hline PS & I 6 & 887 & 968 & 946 & 632 & $5 \cdot 3$ & $5 \cdot 4$ \\
\hline $\mathrm{MJ}$ & II & $118 z$ & 1189 & 1226 & 707 & $6 \cdot 9$ & $6 \cdot 1$ \\
\hline EW & 6 & 529 & 705 & 1017 & 803 & $5 \cdot 7$ & $6 \cdot 9$ \\
\hline $\mathrm{SG}$ & 16 & 1047 & 976 & 937 & 623 & $5 \cdot 3$ & $5 \cdot 4$ \\
\hline \multirow[t]{4}{*}{ JR } & I8 & 945 & I 397 & $95^{8}$ & 803 & $5 \cdot 2$ & $6 \cdot 9$ \\
\hline & Mean & 970 & 1193 & 916 & $7 \circ 3$ & $5 \cdot 1$ & $6 \cdot 0$ \\
\hline & SE & 65 & 74 & 46 & 29 & 0.3 & 0.3 \\
\hline & & \multicolumn{2}{|c|}{$P<0.01$} & \multicolumn{2}{|c|}{$P<$ O.OI } & \multicolumn{2}{|c|}{ NS } \\
\hline \multicolumn{8}{|c|}{ After recovery } \\
\hline DB & 18 & 1080 & $\mathrm{I}_{4} 48$ & $68 z$ & 464 & $3 \cdot 8$ & $4^{\circ} \mathrm{O}$ \\
\hline $\mathrm{JH}$ & 15 & 694 & 660 & 560 & $35 \mathrm{I}$ & $3 \cdot I$ & $3 \cdot 0$ \\
\hline ES & II & 574 & 556 & 464 & 297 & $2 \cdot 6$ & $2 \cdot 5$ \\
\hline PS & 16 & 506 & 572 & 439 & 318 & $2 \cdot 5$ & 27 \\
\hline SG & 16 & 706 & 683 & 473 & 297 & $2 \cdot 7$ & $2 \cdot 6$ \\
\hline \multirow[t]{4}{*}{ JR } & 18 & 638 & 1066 & 469 & 498 & $2 \cdot 6$ & $4 \cdot 3$ \\
\hline & Mean & 700 & $78 \mathrm{r}$ & 515 & $37 \mathrm{I}$ & $2 \cdot 9$ & $3 \cdot 2$ \\
\hline & $\mathrm{SE}$ & 74 & 96 & 33 & 29 & 0.1 & 0.2 \\
\hline & & \multicolumn{2}{|c|}{ NS } & \multicolumn{2}{|c|}{$P<0.02$} & \multicolumn{2}{|c|}{ NS } \\
\hline
\end{tabular}

offered milk $B$, and all the children consumed less than they had done during recovery $(P<0.00$ r for milk $\mathrm{A}$ and $P<0.0$ r for milk B).

Infants from very soon after birth have been shown to have the ability to adjust their food intakes to meet their requirements. Doxiadis \& Paschos (1960) and Fomon, Filer, Thomas, Rogers \& Proksch (I969) have demonstrated that full-term infants given a relatively dilute preparation consume larger volumes than those given a more concentrated one. Nevertheless, energy intakes were lower among infants receiving the dilute preparation, as we found also. It seems reasonable to assume that, in the present study, any further increase in the volume of milk B consumed during recovery was restricted by the limited capacity of the stomach. The amount of milk A consumed was already substantial, and in order to achieve comparable energy intakes a child would have had to take approximately $I \cdot 5 \mathrm{l} / \mathrm{d}$ of milk $B$.

In considering which of the hypothalamic regulatory mechanisms are most likely to be operative in the early days of postnatal life, Widdowson (1971) favours the glucostatic (Mayer, I953) or the thermostatic (Brobeck, 1948) theories or a combination. In our rapidly growing children it is doubtful if the thermostatic mechanism 
could operate during this period (Ashworth, I969a; Brooke \& Ashworth, 1972). During recovery from malnutrition Kennedy's (1953) lipostatic theory appears to fit the facts very well: on admission our subjects had severely depleted fat stores and during recovery their appetites were very great, but after recovery when it is reasonable to assume that fat stores have been repleted appetites fell to more normal levels.

Test periods of $5 \mathrm{~d}$ duration may be criticized as being too short, but this was considered preferable since it was necessary that tests made during the recovery period should be completed well before the children reached their expected weight for height, as we knew from previous experience that food intakes diminished at that point (Ashworth, 1969b). The results have shown that short test periods were indeed necessary as growth rates during recovery were very rapid, with the majority of children gaining more than $200 \mathrm{~g} / \mathrm{d}$ when milk $\mathrm{A}$ was given ad lib.

From a practical point of view this study demonstrates that ad lib. feeding with a standard unmodified milk preparation for the treatment of malnutrition will not achieve the same energy intake as ad lib. feeding with a modified high-energy preparation. This is important if one is concerned about the speed of recovery from malnutrition. A rapid recovery has several obvious advantages both for the patient and for hospital efficiency, but this cannot be achieved unless energy intakes are high. For the majority of malnourished children, once the initial problems of the acutely ill child have been treated, the rate of recovery is proportional to the energy intake. Thus for really effective treatment it is necessary to give a modified preparation with a high energy density; moreover, ad lib. feeding with such a preparation will result in higher energy intakes and more rapid rates of growth than would be found if the volume of feed were restricted.

\section{REFERENCES}

Ashworth, A. (1969a). Nature, Lond. 223, 407.

Ashworth, A. (1969b). Br. $\mathscr{F}$. Nutr. 23, 835 .

Ashworth, A., Bell, R., James, W. P. T. \& Waterlow, J. C. (1968). Lancet ii, 6oo.

Brobeck, J. R. (I948). Yale Y. Biol. Med. 20, 545.

Brooke, O. G. \& Ashworth, A. (1972). Br. F. Nutr. 27, 407.

Doxiadis, S. A. \& Paschos, A. (1960). In Modern Problems in Pediatrics Vol, 7, p. 202 [A. Merminod, editor]. New York: Karger.

Fomon, S. J., Filer, L. J., Thomas, L. N., Rogers, R. R. \& Proksch, A. M. (1969). F. Nutr. 98, 241.

Garrow, J. S., Picou, D. \& Waterlow, J. C. (1962). W. Indian med. F. Ir, 2 I 7.

Kennedy, G. C. (r953). Proc. R. Soc. B r40, 578 .

Mayer, J. (1953). New Engl. F. Med. 249, 13.

Nelson, W. E., Vaughan, V. C. \& McKay, R. J. (r 969). In Texthook of Pediatrics gth ed. [W. E. Nelson, editor]. Philadelphia and London: W. B. Saunders Co.

Widdowson, E. M. (197 r). Proc. Nutr. Soc. 30, 127. 